\title{
'THERE MUST BE A BETTER WAY': PERSONAL INJURIES COMPENSATION SINCE THE 'CRISIS IN INSURANCE'
}

\author{
ANDREW FIELD*
}

It is now six years since the 2002 'crisis in insurance'. It can now be observed that the attributed cause of the crisis - an explosion in common law personal injuries claims - was overstated. It is also evident that the legislature's solution to the crisis was excessive. Statutory amendments took away from injured plaintiffs the right to sue - to the benefit of negligent tortfeasors and their indemnifiers. They assisted private corporations' return to profitability by depriving the injured of the right to compensation. Accordingly, it is now time to consider other alternatives: if not a return to an unfettered common law (the limitations of which have often been discussed), then perhaps other alternatives, including broad-based no fault compensation such as that in use in New Zealand.

\section{INTRODUCTION}

The development of law should be a victory of reason over expediency. However, sometimes the upholding of an ideal can be problematic and sometimes it appears that expediency is victorious. This could be a good description of the law of negligence, how it relates to personal injuries, and the legislative intrusions into that law which occurred in the wake of the 'crisis in insurance' of 2002, leaving many injured persons deprived of a claim.

Until that time the development of the most precocious tort of the last hundred years provided a good illustration of the value of the common law. As Australia's Chief Justice, Murray Gleeson, said recently:

Australia, like all other common law jurisdictions, has experienced the relentless progress of the tort of negligence. Lord Atkin's formulation, in

\footnotetext{
* Senior Lecturer, Department of Business Law and Taxation, Monash University, Barrister-atLaw.
} 
Donoghue $v$ Stevenson ${ }^{1}$, of an over-arching principle to decide when a defendant will be made liable for damage caused to another through failure to take reasonable care was a triumph of common law jurisprudence. ${ }^{2}$

His Honour went on to note that despite this 'triumph', even back in 1932 difficulties in applying the 'duty of care' principle were apparent. ${ }^{3}$ Yet in applying the duty to all manner of persons from owners of property, landlords, employers, large corporations and public authorities to service providers and various other professionals, the courts navigated these difficulties with a degree of success. In a modest way, they were assisted by the legislature. For example, the partial defence of contributory negligence as it has been understood for the last fifty years is wholly the creation of statute. $^{4}$ Nevertheless, despite such assistance, it is fair to say that until recently the development of negligence was mostly the product of judicial decisions.

The perceived 'crisis in insurance' of 2002 was a brutal interruption to this parade. Governments all around Australia perceived a difficulty that they considered was beyond the judges (arguably, they viewed the judges as the cause $^{5}$ ) and they swiftly intervened. The experience in Victoria was reflective

\footnotetext{
${ }^{1}$ [1932] AC 562.

2 Chief Justice Murray Gleeson, 'Australia's Contribution to the Common Law' (Speech delivered at the Singapore Academy of Law, Singapore, 20 September 2007) $<$ http://www.hcourt.gov.au/speeches/cj/cj_20sep07.pdf $>$ at 29 October 2007.

${ }^{3}$ Ibid.

${ }^{4}$ Under the common law, contributory negligence was a complete defence no matter how slight the contribution of the plaintiff. See, for example, Butterfield v Forrester (1809) 103 ER 1134. This position was altered with the passage of the Law Reform (Contributory Negligence) Act 1945 (UK), the provisions of which allowed a plaintiff's action to stand but subject to a reduction in damages based on the plaintiff's share in the responsibility for the damage. This Act provided the model for similar provisions in other jurisdictions including the precursors to section 26 of the Wrongs Act 1958 (Vic). Interestingly, this change in the imperial statute coincides with Ipp J's opinion that in 1945 the development of the law shifted from a position of favouring defendants to favouring plaintiffs.

${ }^{5}$ The description by Federal Assistant Treasurer Senator Helen Coonan of some judges who sought to limit the effects of the common law as 'enlightened judges' certainly indicates that she considered that there were other less 'enlightened' judges who were assisting in expanding the applications of the law of negligence in allocating liability to defendants, leading to claims on their insurers: Helen Coonan, 'Liability Reform: It's Not a Waiting Game' (Speech delivered at the Australian Insurance Law Association, Melbourne, 18 October 2002) $<\mathrm{http}: / /$ www.treasurer.gov.au/atr/content/speeches/2002/021.asp > at 6 November 2007. Justice David Ipp of the New South Wales Supreme Court (who headed the 2002 Review into the Law of Negligence) in a speech to the medical profession also noted that he had heard of judges being blamed for the crisis: Justice David Ipp, 'Judges and Judging' (President's Lecture delivered at the Annual Scientific Congress of Royal Australasian College of Surgeons,
} 
of the rest of Australia. Amendments to the Wrongs Act 1958 (Vic) and other legislation limited the damages that plaintiffs could claim for personal injuries caused by another's negligence. In some cases, the changes abolished the claims altogether.

Were these 'reforms' necessary?

The passing of six years presents a timely opportunity to query whether the changes were really necessary. The added perspective of time allows for the results flowing from the remedies to the 'crisis' to be reviewed. Using the experience in Victoria as a guide, this article aims to consider three issues: first, whether there was actually a 'crisis in insurance', the blame for which could be placed at the door of an over-reliance on the law of negligence; second, whether the crisis justified taking away the right of injured persons to sue, to the benefit of negligent wrongdoers and their indemnifiers; and third, whether there is a better way of compensating injured people.

The third issue is based on the premise that there are obviously concerns regarding the way the tort of negligence has operated, but there are also concerns with the legislative solutions of six years ago. It poses the question of whether there is a better way of compensating for injuries. This question has been posed before. In the 1970s, Australia toyed with the idea of adopting a broad-based no fault compensation scheme similar to that which was introduced in New Zealand in 1974 and continues to this day. At the time, Australia rejected such a scheme in favour of the continued operation of the common law. The arguments in favour of a largely unfettered law of negligence evidently held sway. However, in the ensuing thirty years the law has changed. Even before the 'crisis in insurance', no fault compensation schemes for most transport accidents and workplace injuries were introduced in many states, creating what is effectively a hybrid system of no fault compensation and common law compensation. The further emasculation of the law of negligence in the wake of the 'crisis in insurance' has certainly made that area of tort law a pale shadow of its former self.

Accordingly, in the changed conditions of the first decade of the twenty-first century, it should now be asked again whether Victoria and other Australian jurisdictions are ready for broad-based no fault injury compensation.

Brisbane, 8 May 2003) <http://www.lawlink.nsw.gov.au/lawlink/supreme_court/ll_sc.nsf/ pages/SCO_speech_ipp_080503> at 6 November 2007. 
In summary, this article argues that the blame for the 'crisis in insurance' was incorrectly attributed to an excess of plaintiffs exercising their rights under the existing law, whether their claims were based on negligence or any other cause of action, and that the laws passed on this basis to address the crisis were therefore not justified. It is further argued that these laws abrogating the rights of injured plaintiffs to the advantage of defendants and their underwriters were not only excessive but unjust, and that in light of the compromises now inherent in the law of negligence, which makes it restrictive and complicated, the time is ripe to consider a complete alternative which redresses this imbalance.

\section{The CRIsis in INSURANCE AND ItS CaUses}

Undoubtedly, the insurance industry in the years immediately preceding 2002 was experiencing difficulties. Statistics produced by the Australian Prudential Regulation Authority ('APRA'), ${ }^{6}$ and adopted by the Insurance Council of Australia, ${ }^{7}$ bear out the fact that the industry was incurring losses worth billions of dollars per year, and had been for a few years. There was a crisis that appeared to threaten the viability of the insurance industry. Indeed, it could be broadly suggested that the collapse in 2001 of HIH with losses worth billions of dollars was a clear illustration to the industry - and those who depended on insurance - of where the crisis was heading. ${ }^{8}$ However, the response of government was perplexing. With the benefit of hindsight the identification of causes of the crisis appears more arbitrary than systematic, and driven more by a sense of panic than reason. These traits probably affected the formulation of effective strategies to deal with the crisis.

\section{A Identifying Causes - the Law of Negligence Assertions}

In 2002, not unnaturally, and after consulting with state governments, the Commonwealth Government's substantial response to the crisis (prior to

\footnotetext{
${ }^{6}$ APRA noted, for the insurance industry, underwriting losses of $\$ 2.62$ billion at June 2000; $\$ 1.2$ billion at June 2001; and \$630 million at June 2002: Australian Prudential Regulation Authority, Statistics: Half Yearly General Insurance Bulletin, June 2006 (2007) $<$ http://www.apra.gov.au/Statistics/GI-Half-Yearly-Statistics.cfm> at 30 October 2007.

7 Insurance Council of Australia, Year in Review - 2006 (2007) $<$ http://www.insurancecouncil.com.au/Year-in-review-2006-/default.aspx $>$ at 25 October 2007.

${ }^{8}$ The deficiency in HIH's accounts was estimated at somewhere between $\$ 3.6$ billion and $\$ 5.3$ billion by the Royal Commission established to investigate the collapse of this insurer. See Commonwealth of Australia, HIH Royal Commission, The Failure of HIH Insurance (2003), vol 1, viii.
} 
passing legislation) was to appoint a committee of inquiry. Described as a 'panel of four persons', it was headed by Justice David Ipp of the New South Wales Court of Appeal. However, whereas it might be expected that such a committee would be directed to investigate the causes of the crisis before formulating a response, this committee's terms of reference made it clear that the cause had already been identified. The terms stated:

The award of damages for personal injury has become unaffordable and unsustainable as the principal source of compensation for those injured through the fault of another. It is desirable to examine a method for the reform of the common law with the objective of limiting liability and quantum of damages arising from personal injury and death. ${ }^{9}$

The Panel was not to examine this proposition, and said this early in its final report (the 'Ipp Report'). ${ }^{10}$ Rather, it was directed to '[d]evelop and evaluate principled options to limit liability and quantum of awards for damages. ${ }^{11}$ That even the committee charged with identifying changes to the law should not be required to first identify the causes of the difficulties necessitating such changes is perplexing. The Panel had only two months to deliver its initial report is also reflective of the prevailing attitudes at the time. ${ }^{12}$ Everything was being done in a hurry.

Looked at with the benefit of hindsight, the climate of public debate surrounding the crisis presents three clear characteristics:

First, the debate appears dramatic and beset by panic. Certainly, the reports in the media suggested a degree of panic. Following on from the international reports of the terrorists attacks of 11 September 2001 (the results of which constituted the single largest insurance claim in history ${ }^{13}$ and the collapse of $\mathrm{HIH}$, barely a day in 2002 passed without a report of a business or social gathering being threatened with closure either because it could not obtain

\footnotetext{
${ }^{9}$ Negligence Review Panel, Commonwealth, Review of the Law of Negligence - Final Report (2002) vii <http://revofneg.treasury.gov.au/content/reports.asp> at 30 October 2007.

${ }^{10}$ In fact, in the Panel's final report, it is stated that '[ $\left.\mathrm{t}\right] \mathrm{he}$ Panel's task is not to test the accuracy of these perceptions but to take as a starting point for conducting its inquiry the general belief in the Australian community that there is an urgent need to address these problems': Ibid [1.6].

${ }^{11}$ Ibid vii.

${ }^{12}$ The terms of reference were dated 2 July 2002, with portions of the report due by 30 August 2002, and the remainder due on 30 September 2002: Ibid ix.

13 Philip McGuire, Deputy CEO of Insurance Council of Australia, speaking on ABC Television, 'Ministers meet to address public liability crisis', Landline, 7 April 2002 $<$ http://www.abc.net.au/landline/stories/s518565.htm> at 30 October 2007.
} 
insurance or could not afford to pay rapidly rising insurance premiums. There were reports of builders' insurance increasing by up to 150 per cent. ${ }^{14}$ Public liability insurance had also increased. At one stage it was suggested that in future years the Royal Melbourne Show might not go ahead on account of its premiums having tripled in the previous four years. ${ }^{15}$ Providers of all manner of recreational activities were also under threat, whether they were operators of basketball courts ${ }^{16}$ or camel trek rides. ${ }^{17}$ Members of the medical profession reportedly were also considering their options after the provider of medical indemnity, UMP, was placed into liquidation. ${ }^{18}$ One report even told of how the entire town of Mansfield had ceased business for a day on account of insurance concerns. ${ }^{19}$ To view the reports from the distance of six years is to witness the building of a frenzy - not the ideal environment in which to formulate policy.

Second, most media commentators and lawmakers immediately fastened on the operation of the law as the cause of the crisis, and particularly the law relating to compensation for personal injuries. This is well reflected by the views of Senator Helen Coonan who was the minister responsible for the terms of reference for the Ipp Report. Later in 2002, Senator Coonan stated:

There is a widely held view that the current problems in the insurance market are due in large part to the operation of the legal system. It is clear that the broader community is dissatisfied with the seemingly random nature of court awards. There is also a strong perception that an increasing culture of blame has emerged within our society. This has led individuals to seek redress through the legal system, where in similar circumstances in the past, the individual would have been more prepared to assume responsibility for the consequences of their own actions. ${ }^{20}$

Third, despite the causes of the crisis being regularly attributed to the operation of the law and litigation and the rise of the 'blame' society, there was little empirical or statistical evidence presented to support such

\footnotetext{
${ }^{14}$ Linda Morris, 'Building Insurance UP 150\%', Sydney Morning Herald (Sydney), 6 February 2002,3 .

${ }^{15}$ McGuire, above n 13.

16 'Insurance Crisis May Crush Sport Teams', The Age (Melbourne), 6 August 2002.

${ }^{17}$ Kathleen Cuthbertson, 'Insurance Anger Stops Mansfield', Herald Sun (Melbourne), 15 March 2002, 24.

${ }^{18} \mathrm{ABC}$ Television, 'Doctors' Insurance Crisis', Lateline, 29 April 2002 $<$ http://www.abc.net.au/lateline/stories/s543171.htm> at 30 October 2007.

${ }^{19}$ Cuthbertson, above $\mathrm{n} 17$.

${ }^{20}$ Helen Coonan, 'Insurance Premiums and Law Reform - Affordable Cover and the Role of Government' (2002) 25 University of New South Wales Law Journal 819, 819.
} 
attribution. Although there was frequent use of anecdotal evidence of large awards of compensation being made, ${ }^{21}$ and it was asserted that the numbers of such awards were increasing, ${ }^{22}$ a regular complaint of commentators was that facts and figures were wanting. ${ }^{23}$ Indeed, although insurers sought restrictions in plaintiffs' rights to sue on account of the effects that these growing numbers of lawsuits had had on their businesses, it was pointed out that the insurers were 'reluctant to reveal their claims experience', and provide the evidence of such an increase. ${ }^{24}$

\section{B Identifying Causes - Litigation Statistics}

Planning a legal reform which will take away plaintiffs' substantive rights on the basis of inadequate information can lead to ineffective reform, particularly if adequate information might have led to different conclusions. And yet, adequate information was available. Although they did not receive as much coverage as the stories of anecdote and assertion, there were contemporaneous attempts made to present a statistical picture of litigation trends. For example, Rob Davis of the Australian Plaintiff Lawyers Association cited data of the Australian Productivity Commission to show that there was actually evidence of a decline in personal injuries litigation towards the end of the $1990 \mathrm{~s} .{ }^{25} \mathrm{He}$ also explained that, although in some individual jurisdictions there might have been cases of increased personal

\footnotetext{
${ }^{21}$ See, for example, the report of a payout of $\$ 5.7$ million to a wrestler left a quadriplegic after a training accident: Shaun Phillips and Karen Collier, 'Sports Insurance Premiums May Double', Herald Sun (Melbourne), 8 May 2002, 6. Interestingly, in reflecting the view that this perception of large payouts is based on limited, unusual and 'newsworthy' cases, Queensland Chief Justice Paul de Jersey, when recently describing the 2002 experience, felt the need to draw on the recent case in the United States of a junior judge launching a \$64 million lawsuit over damage caused to his trousers by a drycleaner. Although the Chief Justice's point was that such accounts did not help the reputation of the legal system, he also had to concede that this lawsuit did not accord with the 'local reality': Chief Justice Paul de Jersey, 'A Review of the Civil Liability Act and Tort Reform in Queensland: Opening Plenary Forum Discussion' (Speech delivered at the Queensland Law Society Personal Injuries Conference, Brisbane, 29 June 2007) < http://archive.sclqld.org.au/judgepub/2007/dejersey290607.pdf > at 7 November 2007.

${ }^{22}$ And yet, in at least one empirical study, although it has been noted that awards of damages have increased between 1980 and 2000, it has also been pointed out that high awards of compensation are exceptional, and that generally awards are not excessive: Peter Abelson, 'Is Injury Compensation Excessive?' (2004) 23 Economic Papers 129.

${ }^{23}$ See, eg, Reg Graycar, 'Public Liability: A Plea for Facts' (2002) 25 University of New South Wales Law Journal 810.

${ }^{24}$ Harold Luntz, 'Reform of the Law of Negligence: Wrong Questions - Wrong Answers' (2002) 25 University of New South Wales Law Journal 836, 837.

${ }^{25}$ Rob Davis, 'The Tort Reform Crisis' (2002) 25 University of New South Wales Law Journal $865,866$.
} 
injury litigation, these were more than balanced by a decline in other jurisdictions. ${ }^{26}$

More recently, the 2006 study by Professor E W Wright of the University of Newcastle provided evidence of a clear trend reflecting a decline in litigation prior to $2002 .^{27}$ His study tallied the personal injury claims from the Supreme, County and District Courts around Australia. Rather than merely compiling raw total numbers of claims - which in a rising national population would be expected to rise - his figures were presented in terms of the number of claims per 10,000 members of the population. On this basis, Wright's figures indicated that, although there had been a slight increase in claims in the late 1990s - from 4 to 5 - this had dropped off again by 2000 , only then spiking in 2002 in anticipation of the post-Ipp reforms. ${ }^{28}$ In other words, if there was a 'crisis in insurance', it was not caused by any radical increase in litigants using the law to seek compensation from defendants and their insurers for their personal injuries. Accordingly, the expression 'tort law crisis', which is sometimes also deployed to describe the situation, ${ }^{29}$ is inaccurate, except in so far as it described the oncoming curtailment of legal rights to compensation.

\section{Identifying Causes-Other Causes}

If a rampant culture of litigation and attribution of blame was not the cause of the crisis, what other causes might be suggested? Interestingly, in an apparent demonstration of putting the cart before the horse, some months after the delivery of the Ipp Report the Economics References Committee of the Australian Senate presented its report into public liability and professional indemnity. ${ }^{30}$ This committee identified three causes of the crisis:

\footnotetext{
${ }^{26}$ Ibid 867.

${ }^{27}$ E W Wright, "National Trends in Personal Injury Litigation: Before and After "Ipp"' (2006)

14 Torts Law Journal 233.

${ }^{28}$ Ibid 248.

${ }^{29}$ See, for example, Paul Latimer, Australian Business Law $\left(26^{\text {th }}\right.$ ed, 2007) 217.

${ }^{30}$ Economics References Committee, Parliament of Australia (Senate), A Review of Public Liability and Professional Indemnity Insurance (2002).
} 
- international influences including the withdrawal of capacity and the increasing cost of reinsurance following the destruction of New York's World Trade Centre in terrorist attacks on September 11, 2001;

- the 'hardening' of the insurance market as, after a period of underpricing and poor profitability in the mid 1990s, insurers now focus on improving profitability rather than merely increasing market share; and

- the increasing cost of claims. ${ }^{31}$

The last of these three has already been noted. ${ }^{32}$ However, what of the other two? Where did they feature in the terms of reference of Justice Ipp's Review of the Law of Negligence?

In fact, they appear elsewhere as suggested reasons for a downturn in the fortunes of the insurance industry. In addition to being pointed to by the Economics References Committee, they were also discussed by one other significant government inquiry into a major player in the insurance industry: the Royal Commission into the collapse of $\mathrm{HIH}^{33}$ And yet, when the Royal Commission into the collapse of HIH investigated the reason for that collapse, it focused on a further cause of the collapse of that particular insurer. The collapse of HIH could be viewed both as being emblematic of the crisis in insurance, and also as suggesting a further cause of the difficulties besetting the insurance industry.

HIH was a large insurer - indeed one of the 'major players' in Australia ${ }^{34}$ and it collapsed. The obvious observation is that if such a large market leader could go under, then things must be difficult in insurance. And yet, the Commissioner Neville Owen found the causes of the collapse to be specific to HIH. Although he noted the global downturn in the insurance industry, he also observed that the market was cyclical and that other insurers 'weathered the storm'. ${ }^{35}$ He also noted that, although HIH had experienced losses in its underwriting business, this is not fatal if other aspects of the business such as investment of policy holders' funds return a profit. ${ }^{36}$ However, what ultimately condemned HIH in Commissioner Owen's opinion was that this company was mismanaged and dominated by a flawed corporate culture. $\mathrm{He}$ said:

\footnotetext{
${ }^{31} \operatorname{Ibid}[2.1]$.

${ }^{32}$ See text under Heading 2(a) above.

${ }^{33}$ See generally Commonwealth of Australia, HIH Royal Commission, The Failure of HIH Insurance (2003).

${ }^{34}$ Economics References Committee, above n 30, [2.14].

${ }^{35}$ HIH Royal Commission, above $\mathrm{n} 32$, xvi.

${ }^{36}$ Ibid xviii.
} 
The answer here is that $\mathrm{HIH}$ was mismanaged. The factors contributing to the mismanagement of the group - and hence the reasons for the failureare many, varied and complex. They are also interrelated. They are epitomised by a lack of attention to detail, a lack of accountability for performance, and a lack of integrity in the company's internal processes and systems. Combined, these features led to a series of business decisions that were poorly conceived and even more poorly executed. ${ }^{37}$

Of the firm's culture, the Commissioner stated:

There was blind faith in a leadership that was ill-equipped for the task. There was insufficient ability and independence of mind in and associated with the organisation to see what had to be done and what had to be stopped or avoided. Risks were not properly identified and managed. Unpleasant information was hidden, filtered or sanitised. And there was a lack of sceptical questioning and analysis when and where it mattered. ${ }^{38}$

As for any clear fraud or dishonesty, although it existed, the Commissioner explained that ' $[\mathrm{m}]$ ost of the instances of possible malfeasance were borne of a misconceived desire to paper over the ever-widening cracks that were appearing in the edifice that was HIH. ${ }^{39}$ In other words, the collapse of $\mathrm{HIH}$ was not caused by either an increasingly litigious community, or a devastating downturn in the insurance market. Its troubles were the result of internal failures and a fatally flawed and ineffective record of corporate governance. $^{40}$

In summary, in considering the causes of the crisis in insurance, in addition to the causes identified by the Economics References Committee, might it not also be the case that other insurers were subject to the same difficulties which beset $\mathrm{HIH}$, albeit to a lesser extent? ${ }^{41}$

\footnotetext{
${ }^{37}$ Ibid xvii.

${ }^{38}$ Ibid.

${ }^{39}$ Ibid xvi.

${ }^{40}$ These aspects of the Commissioner's report are emphasised in Phillip Lipton, 'The Demise of HIH: Corporate Governance Lessons' (2003) 55(5) Keeping Good Companies 273. See also Gregor Allen, 'The HIH Collapse: A Costly Catalyst for Reform' (2006) 11 Deakin Law Review 137, in which it is queried whether legislative changes to auditing standards will be either effective or workable. In fact, the sub-text to such a study is that, despite the flawed auditing in detecting the mismanagement at $\mathrm{HIH}$, it was nevertheless still the directors and officers of that company who were responsible for its collapse and not an inadequacy in the law.

${ }^{41}$ In making this statement, it is an underlying assumption that the corporate model of many large insurance companies has many inefficiencies which arguably have made the provision of insurance to the consumer more costly than was once the case. Specifically, for example, the global wave of demutualisations in the insurance sector since the 1980s has now diverted the
} 


\section{EFFECTS OF THE CRISIS IN INSURANCE}

\section{A Legislative Changes}

Adding to the perplexing approach taken to deal with the crisis in insurance already outlined, the legislative innovations introduced by the various Australian jurisdictions had a further puzzling dimension. In an apolitical approach, both Liberal and Labor politicians at both levels of government supported the push for legislative change. However, although the States had supported the Commonwealth in commissioning the Ipp Report, and the Ipp Report had recommended that any legislative changes be uniformly enacted around the country, ${ }^{42}$ uniformity was soon abandoned. Even before the final report was released those same States jumped the gun. Although they were criticised for it, they nevertheless commenced passing their own legislation to change the law of negligence. ${ }^{43}$

In Victoria, the Wrongs Act 1958 was heavily amended through three different pieces of legislation passed in $2002,{ }^{44}$ and $2003 .{ }^{45}$ Many of the changes codified certain concepts relating to the law of negligence. ${ }^{46}$ Some

focus of the insurers' energies away from the primary goal of providing for the insurers' former members. The trend has been as apparent in Australia as overseas: See Reserve Bank of Australia, 'Demutualisation in Australia' (1999) Reserve Bank of Australia Bulletin, $<$ http://www.rba.gov.au/ PublicationsAndResearch/Bulletin/bu_jan99/bu_0199_1.pdf $>$ at 27 November 2007. Once demutualised, the satisfaction of shareholders and their need for dividends and capital growth must supplant the previous primary goal of fund members' interests. In addition, the salary aspirations of directors and officers of these demutualised insurers also have the effect of increasing costs. To illustrate this point, in the United Kingdom, although a recent inquiry found as a general trend that demutualised insurers performed no better after demutualisation, salaries of their directors had grown appreciably. Further, across a range of indicators in relation to life assurance, continuing mutual insurers performed more successfully than former mutuals, and passed on the financial benefits accruing from these successes to their members: See All Parliamentary Group for Building Societies and Financial Mutuals (United Kingdom), Windfalls or Shortfalls? The True Cost of Demutualisation (2006) <http://www.mutuo.co.uk/pdf/windfallsorshortfallsfinal.pdf $>$ at 27 November 2007.

${ }^{42}$ Negligence Review Panel, above n 9, [2.1].

${ }^{43}$ Andrew White and Amanda Keenan, 'Insurance Reform in Chaos - NSW and Victoria Go Their Own Way in Face of Federal Blueprint', The Australian (Sydney), 3 September 2002, 1. Interestingly, some newspapers presented a more positive headline to the reports, but nevertheless also explained that there were differences in approach across the various jurisdictions: See, for example, Linda Morris, 'Leaders Unite for National Approach to Liability Laws', Sydney Morning Herald (Sydney), 3 October 2002, 6.

${ }^{44}$ Wrongs and Other Acts (Public Liability Insurance Reform) Act 2002 (Vic).

${ }^{45}$ Wrongs and Limitation of Actions Acts (Insurance Reform) Act 2003 (Vic); Wrongs and Other Acts (Law of Negligence) Act 2003 (Vic).

${ }^{46}$ See Wrongs Act 1958 (Vic) pt X, introduced in 2003. 
set down principles regarding proportionate liability and contribution. ${ }^{47}$ Others, however, went further. A new Part VB introduced a number of caps on damages, including: first, a cap on damages for loss of earnings equal to three times the average weekly earnings of a Victorian employee as determined by the Australian Statistician; ${ }^{48}$ and, second, an indexed cap on non-economic loss (or 'general') damages of $\$ 371,380 .{ }^{49}$ Arguably, the effect of these changes was confined to limited classes of plaintiffs. The first cap, for example, only limited damages to those plaintiffs who might be described as high-income earners. Similarly, the effect of the cap on non-economic loss damages was arguably small. This is because only a small number of cases will create the circumstances for an award of such damages accounting for pain and suffering, loss of amenity and enjoyment of life greater than this sum. Nevertheless, in cases where damages are assessed that are in excess of both of these the capped amounts, there is arguably an injustice when the payment of the damages cannot be made because of these caps. Injured plaintiffs must bear this loss themselves, rather than the negligent defendants doing so. ${ }^{50}$

Further, although its effect is also limited, an injustice can also be identified in section $28 \mathrm{C}(3)$ which states that the Part VB caps extend to personal injury damages 'even if the damages are recovered in any action for breach of contract or in any other action. ${ }^{, 51}$ What of the situation where the damage was caused by way of an intentional tort and not mere negligence? Unlike similar post-Ipp legislation in New South Wales and South Australia which specifically excluded extending the caps to intentional torts, ${ }^{52}$ in Victoria the

\footnotetext{
${ }^{47}$ See Wrongs Act 1958 (Vic) pts IV, IVAA.

${ }^{48}$ Wrongs Act 1958 (Vic) s 28F.

${ }^{49}$ Wrongs Act 1958 (Vic) s $28 \mathrm{G}$.

50 The same argument can be made for other damages assessments which are now capped, including, for example, the cap on damages for 'gratuitous attendant care' under section 28IB, and also damages for loss of capacity to provide care for others under section 28IE. For a recent example of what sort of damages are covered under this latter heading, see CSR Limited $v E d d y$ [2005] HCA 64, in which compensation was claimed for a plaintiff's inability to provide domestic assistance to his blind wife and the court made brief comments on the Victorian legislation.

${ }^{51}$ Wrongs Act 1958 (Vic) s 28C(3).

${ }^{52}$ In New South Wales, section 3B(1)(a) of the Civil Liability Act 2002 specifically excludes from the operation of the reforms 'civil liability in respect of an intentional act that is done with intent to cause injury or death'. Similarly, in South Australia, section 51(a)(ii) of the Civil Liability Act 1936 (SA) applies the reforms only to 'accidents caused wholly or in part by negligence or some other unintentional tort.
} 
intentional tortfeasor is protected from the full weight of the common law through the broad reach of the caps. ${ }^{53}$

More striking because of its broad application to a large number of injured persons was the introduction, in the new Part VBA of the Wrongs Act 1958 (Vic), of a threshold for claims for non-economic loss. ${ }^{54}$ When introducing the amendment, the Victorian Premier, Mr Bracks, explained that for small claims - meaning claims of $\$ 50,000$ or less - half of the damages paid are general damages. ${ }^{55}$ Therefore, citing businesses and professionals who were 'concerned about the cost of meeting a succession of minor claims', 56 the State Government, rather than requiring these businesses to observe their duty of care, instead abolished plaintiffs' rights to these 'minor claims'. This was done by requiring that the person injured must establish that they had suffered a 'significant injury'. 57 'Significant injury' was defined as meaning an injury assessed as being either above the 'threshold level' of more than 5 per cent bodily impairment (or 10 per cent impairment for a psychiatric injury), or the loss of a breast or foetus. ${ }^{58}$ Anything less would not be compensated. $^{59}$ A staggering amendment, but one of broad application, ${ }^{60}$ it effectively set the untreated pain and suffering of individuals who failed to establish significant injury, and the consequent effects of that pain, at naught, wholly to the benefit of the tortfeasors. ${ }^{61}$

\footnotetext{
${ }^{53}$ Although it has not been tested, there is perhaps one way that plaintiffs in Victoria can circumvent this broad rule. Specifically, although in section 21 of the Civil Liability Act 2002 New South Wales adopted the Ipp Report recommendation to abolish exemplary damages, the Victorian legislation in contrast was generally silent on this point. Thus, although such damages are very rarely awarded in Australian jurisdictions, they could theoretically find a place in the arguments of those injured through intentional wrongs and provide scope for compensation beyond the limits set down in the Wrongs Act 1958 (Vic).

${ }_{54}^{54}$ Wrongs Act 1958 (Vic) s 28LE.

${ }^{55}$ Victoria, Parliamentary Debates, Legislative Assembly, 21 May 2003, 1782 (Steve Bracks, Premier).

${ }^{56}$ Ibid.

${ }^{57}$ Wrongs Act 1958 (Vic) s 28LE.

${ }^{58}$ Wrongs Act 1958 (Vic) ss 28LB, LF.

${ }^{59}$ Wrongs Act 1958 (Vic) s 28LE.

${ }^{60}$ A similar threshold for pain and suffering compensation was also applied to the Victorian no fault compensation scheme for workplace injuries: Accident Compensation Act 1985 (Vic) s 98C. In contrast, under the no fault scheme in relation to transport injuries, the right to claim for pain and suffering only arises if a 'serious injury' is identified and common law proceedings allow it: Transport Accident Act 1986 (Vic) s 93. The no fault schemes are discussed in the text below.

${ }^{61}$ In addition, although there is little judicial discussion on this point, considering the history of the related threshold of 'serious injury' which is used in relation to transport accidents and workplace accidents to allow common law claims, it would be very surprising if the expression 'significant injury', despite the exhaustive definition, is given anything other than a restrictive
} 
Other very significant legislative changes also appeared. For example, it was recognised that many personal injuries claims are for breach of contract, based on injuries caused when plaintiffs are engaged in recreational activities. Therefore, just as the Commonwealth amended the Trade Practices Act 1974 in 2002, ${ }^{62}$ the Victorian Government followed suit and amended its equivalent statute, the Fair Trading Act $1999 .{ }^{63}$ The amendments of both Acts now allow providers of recreational services (i.e. providers of sporting or leisure activities undertaken for enjoyment which involve a degree of physical exertion or risk) to contractually exclude their liability for injury or death even if this damage is caused by a lack of due care and skill on their part. Even six years later, the implications of these amendments are staggering. For example, the purchaser of a tourist flight or bungee jump, not being an expert, relies on the skills of their provider. However, since 2003, that provider will not be liable if an appropriate disclaimer has been signed. The user, perhaps suffering all manner of injuries, is now thrown onto their own resources. For this reason, the criticism has been made that although the legislature was seeking to wind back excessive personal injuries claims and 'achieve a balance between protecting consumers and allowing them to take responsibility for themselves', by allowing providers to contract out of all of their liability the new sections have gone too far. ${ }^{64}$

Finally, other amendments were designed to close off alternative causes of action which might circumvent the amendments already noted. For example, the enactment in 2006 of section 82 (1AAA) of the Trade Practices Act ${ }^{65}$ was specifically designed to prevent forum shopping between state and federal courts. ${ }^{66}$ One of its results was to prevent claims for death or personal injury arising from 'misleading and deceptive conduct' in breach of section 52 from coming to court.

meaning. On the topic of 'serious injuries', it has been argued that the courts' interpretation of this expression sets a much higher threshold than is suggested by the relevant legislation: Andrew Field, 'Just How Serious is Section 93: A Re-evaluation of Humphries v. Poljak' (1997) 71(9) Law Institute Journal 34.

${ }^{62}$ See section 68B, inserted by the Trade Practices Amendment (Liability for Recreational Services) Act 2002 (Cth), s1.

${ }^{63}$ See section 32N, inserted by the Fair Trading (Amendment) Act 2003 (Vic), s11 and the Fair Trading (Further Amendment) Act 2003 (Vic), s24

${ }^{64}$ See Natasha Schot, 'Negligent Liability in Sport' (2005) 1 Sports Law eJournal 1.

${ }^{65}$ Inserted by the Trade Practices Amendment (Personal Injuries and Death) Act 2006 (Cth), s3 and Sch 1 item 2.

${ }^{66}$ Commonwealth, Parliamentary Debates, House of Representatives, 9 December 2004, 11 (Malcolm Brough, Minister for Revenue and Assistant Treasurer). 


\section{B Litigation Changes}

The effects of these legislative changes were apparent relatively quickly. In terms of litigation, the effects can be seen in two ways.

First, there has been the effect on court lists. Although, in anticipation of the legislation, there was an initial spike in personal injuries claims brought before the courts, the following five years saw a downturn in such litigation. Initial trends were identified relatively quickly. For example, in December 2004, the Law Institute of Victoria was citing County Court statistics which indicated that, in the preceding 12 months, the number of personal injury writs issued had dropped 88 per cent compared with the previous year. ${ }^{67} \mathrm{Just}$ over a year later, the Institute was citing figures indicating that the trend was continuing, with public liability law suits dropping by 95 per cent from a yearly figure of 1735 before the reforms to a mere 84 in the year $2005 .^{68}$ The position in New South Wales was similar, the Chief Justice himself commenting on the 'dramatic change' in the practical operation of the law of negligence wrought by statute, with personal injuries filings in the District Court dropping from 19,000 filings in 2001/2002 to 5,500 in 2004/2005. ${ }^{69}$ Undoubtedly these comments give the impression of a collapse in court lists.

More recently, the study by Wright referred to above ${ }^{70}$ and published in 2006 presents the trends up to the end of 2005 in a no less dramatic light. As noted, Wright culled figures from the statistics of the State District, County and Supreme Courts and produced figures indicating both raw numbers of claiming rates per ten thousand members of the population. For Victoria, Wright's figures show actions commenced in 2001 as being just over 1200 (2.69 per 10,000 people), spiking to 2570 (5.30 per 10,000 people) in 2003 in anticipation of the legislative changes, and settling at just over 200 claims ( 0.5 per 10,000 people) in 2004 and 2005 in the wake of the changes. ${ }^{71}$ His comment is that the decrease in claims now gives Victoria the distinction of being the lowest claiming state in Australia. Reflecting this, Wright's conclusion regarding what occurred in courts across the nation is as follows:

$[T]$ he corrections (if this is the right term) wrought to personal injury claiming rates by the reforms in Queensland, New South Wales and Victoria

\footnotetext{
${ }^{67}$ Law Institute of Victoria, 'Tort Law "Reform" Side Effects Hit Home' (2004) 78(12) Law Institute Journal 21.

${ }^{68}$ Law Institute of Victoria, 'Tort Stats Spark Call for Review' (2006) 80(7) Law Institute Journal 27.

${ }^{69}$ Chief Justice James Spigelman, 'Tort Law Reform: An Overview', (2006) 14 Tort Law Review 5.
} 
have been dramatic: claims in New South Wales have fallen by over $63 \%$, in Queensland by more than $70 \%$ and in Victoria by a breath-taking fourfifths $(80 \%)^{72}$

Of course, the injured parties have not vanished into thin air. They have simply been deprived of the ability to make a claim against those whose negligence caused their loss.

The second effect is also noteworthy, although, as the above figures indicate, its impact has been minimal. It has been the creative way in which alternative personal injury claims have been brought so as to circumvent the changes. For example, in New South Wales and South Australia where the new limitations on claiming were essentially limited to negligence claims, the intentional torts have proved a possible alternative. ${ }^{73}$ This alternative has not proved so profitable in Victoria because (as noted above ${ }^{74}$ ) the Victorian legislation was drafted so as to have a broader application. It was stated to apply not just to negligence but to 'any other action', an expression which would appear to include the various intentional torts. ${ }^{75}$ However, claims have been successfully brought which appear not to be subject to the new regime. These claims include those either set out under section 28C(2) of the Wrongs Act 1958 (Vic) and which are already subject to their own caps (such as transport accidents), or those which, through a drafting oversight, have 'fallen through the cracks'.

Although examples of these claims are few and far between, one example is the 2007 decision in Hynes $v$ Hynes. ${ }^{76}$ In this case, the plaintiff brought a common law claim for compensation for physical and psychological injuries caused by the negligence of the defendant. These injuries were caused when the defendant having removed the cap from the overheated radiator of his car, boiling water suddenly erupted striking and injuring the plaintiff. On the facts, neither cap nor threshold under the Wrongs Act 1958 (Vic) applied because the relevant provisions of this Act expressly did not apply to the

\footnotetext{
${ }^{70}$ Wright, above n 27

${ }^{71}$ Ibid 254.

${ }^{72}$ Ibid 266.

${ }^{73}$ See above n 52. See also: Tina Cockburn and Bill Madden, 'Intentional Torts to the Person, Compensation for Injury and the Civil Liability Acts' (2007) 18 Insurance Law Journal 1, 5-8.

${ }_{75}^{74}$ See above $\mathrm{n} 51$.

${ }^{75}$ However, in Esso Australia v Robertson [2005] VSCA 138, it was determined that the Part VBA thresholds for claiming non-economic damages do not have such a wide application, as the terms of s $28 \mathrm{C}(3)$ do not appear in or apply to that part. Thus, a compensation payment under s 85B of the Sentencing Act 1991 was allowed without applying the threshold.

${ }^{76}$ [2007] VSCA 7.
} 
parts of the Transport Accident Act 1986 (Vic) which related to common law claims such as the plaintiff's. Similarly, although the Transport Accident Act imposed its own thresholds and damages limits under section 93, the injury in question, not being caused by the 'driving of a car', did not fall within that section, meaning those thresholds and limits did not apply. The claim did, however, fall within section 94 which provided that the Transport Accident Commission would indemnify any driver in respect of any liability arising out of the 'use of a motor car'.

However, such cases are the exception. The overwhelming effect on litigation has been to see injured persons cease to bring claims. No doubt such persons are still present in the community, and their injuries have been caused by the negligence of others. However, they have been deprived of their right to claim.

\section{Insurance Industry Changes}

In contrast to injured persons, the insurance industry in Australia is in a much stronger position today than was the case in 2002. Undoubtedly the crisis in insurance marked a turning point for the industry. From the industry-wide losses, worth billions of dollars, that it was experiencing it went into the black in 2003. Specifically, according to the figures published by APRA, ${ }^{77}$ underwriting results rose from losses to profits of: $\$ 1,848$ billion in 2003; $\$ 3,614$ billion in 2004; $\$ 2,641$ billion in 2005; and $\$ 3,132$ billion in 2006 . Net profits also re-entered the black in 2003 reaching \$5,600 billion in 2006 .

In commenting on this trend, the Insurance Council of Australia has said:

The public liability reforms have been very successful. The partnership between the insurance industry, the community and government has resulted in more available and more affordable public liability premiums for consumers. $^{78}$

Undoubtedly, by preventing a range of lawsuits, legislative changes assisted the insurance industry return to profit. However, when it is recalled that the urgency of the changes was promoted on account of the increase in the price of premiums, the 'partnership' appears one-sided. In the year after the changes were introduced, reports were still appearing in the media of both professional and recreational activities being under threat because of the price

\footnotetext{
77 Australian Prudential Regulation Authority, above n 6. Once again, the figures were also adopted by the insurance industry: Insurance Council of Australia, above $\mathrm{n} 7$.
} 
of premiums. ${ }^{79}$ The general impression to be gained from such reports was that the price of premiums had not dropped.

More recently, in a 2005 report commissioned by the Law Council of Australia, Richard Cumpston made the same point, querying whether 'high insurer profits allow better benefits to the injured'. ${ }^{80}$ While noting that Australian insurers were arguing that after-tax profits on capital of about twelve to fifteen per cent were reasonable, Cumpston observed that, although direct insurers obtained returns averaging between eight and eleven per cent in the eleven years to June 2004, these returns had jumped to 23 per cent in the six months to December 2004. ${ }^{81}$ Cumpston's observations regarding third party insurers, public liability insurers and medical indemnity insurers also revealed returns well above the 'reasonable' figures. His conclusion was that '[t]he profits and capital of insurers appear high enough to allow better benefits to injured persons, particularly those most harshly affected by recent legislative changes. ${ }^{, 82}$

Thus, the appearance is given of an insurance industry which has grown strong and profitable on account of legislative changes that have prevented plaintiffs initiating claims that previously had drawn on industry funds. Further, it is an effect which has been magnified by a failure of the industry to decrease its premiums in a meaningful way.

\section{A Time to Embrace the No Fault Option?}

The preceding discussion indicates that a key effect of the crisis in insurance and its consequent developments has been to see the common law diverted far away from the interests of the injured and in favour of the interests of defendants and private businesses. It is unlikely that this was the intention of the legislators, at least in terms of degree. However, it was the result.

\footnotetext{
${ }^{78}$ Insurance Council of Australia, above n 7, 21.

${ }^{79}$ See, for example: Susie O’Brien, 'New Crisis Hits Events Insurance', Herald Sun (Melbourne), 19 June 2003, 29; Law Society of New South Wales, 'Will the Sausage Sizzle This Christmas', (Press release, 11 December 2003); Kenneth Davidson, 'How to Solve the Medical Indemnity Crisis', The Age (Melbourne), 16 October 2003.

${ }^{80}$ Richard Cumpston, 'High Insurer Profits Allow Better Benefits to the Injured?', (Paper presented at the Personal Injury and Compensation Forum held by the Law Council of Australia, Sydney, 3 June 2005) <http://www.lawcouncil.asn.au/tortreform.html $>$ at 22 November 2007.

${ }^{81}$ Ibid 1.

${ }^{82}$ Ibid.
} 
The legislative changes which produced this result do not represent the first occasion on which injured plaintiffs have been deprived of their rights to sue under the common law. Indeed, the last twenty years have seen this occur in most states of Australia at one time or another and in limited circumstances. However, when such rights have been abrogated by statute, they have usually been replaced with some form of compensation scheme. This has been the dominant effect of workers' compensation schemes and transport accident compensation schemes. ${ }^{83}$ Generally, plaintiffs have not been left standing high and dry without some form of claim to compensation. It is in so far as they offered no substitute for common law actions that the amendments to the Wrongs Act 1958 (Vic) and other legislation were significant.

In this context, when the common law is now so skewed, perhaps it is time to consider changes to the existing system of compensating the injured. Perhaps it is time not merely to tinker around the edges, but rather to consider a wholesale replacement of the use of a trial as a means toward compensation. After all, if the only way to make the system workable is to deprive the innocently injured of access to compensation, then perhaps the system is hopelessly flawed and in need of replacement.

Although this suggestion is anathema to most practising common lawyers whose livelihood has been built on the existing system, the suggestion is neither new nor wholly theoretical. Indeed, it was actually the basis for the introduction of the no fault compensation scheme in New Zealand. It was also the basis for the introduction of similar limited schemes here in Australia. These examples and the reasons for their introduction warrant some examination.

\section{A No Fault Compensation in New Zealand}

New Zealand has had a broad-based no fault compensation scheme which has largely replaced the common law since $1974 .{ }^{84}$ Its original manifestation was in the Accident Compensation Act 1972. The impetus for the scheme came

\footnotetext{
${ }^{83}$ See for example the Transport Accident Act 1986 (Vic) which although under s93 it abolished common law claims for compensation for injuries caused as a result of driving a motor car unless the injury constituted a "serious injury", at the same time under s35 introduced payments of compensation under a no fault scheme.

${ }^{84} \mathrm{As}$ is the case with plaintiffs in Australia seeking to circumvent the reforms of 2002 which limited common law claims, in New Zealand plaintiffs have also been creative in their efforts to bring claims in those limited situations which fall outside the terms of the no fault scheme. See Alisa Duffy, 'The Common Law Response to the Accident Compensation Scheme' (2003) 34 Victoria University of Wellington Law Review 367.
} 
from the perceived inefficiencies and inequities of the way the common law dealt with person injuries claims.

When the 1967 Royal Commission, chaired by Sir Owen Woodhouse, investigated these perceived flaws, it found that, although the common law delivered benefits to a few, it did so at an extraordinarily high cost. ${ }^{85}$ Specifically, administration and other charges absorbed 'as much as $\$ 40$ for every $\$ 60$ paid over to successful claimants'. ${ }^{86}$ This was a significant consideration. However, other difficulties inherent in the trial process also raised concerns. These included delays and costs, the effects of these matters on evidence, and the further compounding effects of navigating the vicissitudes of the legal system. And in those cases when these difficulties were overcome, the final crowning once and for all time 'guesstimate ${ }^{87}$ of damages which was to be made for the successful plaintiff - an estimate which must take into account many years of future loss - raised serious concerns. They turned the claims system into an imprecise and wasteful faultfinding exercise having more in common with a lottery than a scheme focused on compensating the injured. ${ }^{88}$ These concerns have been discussed at length many times before, ${ }^{89}$ and space does not permit a thorough discussion of them in this article. For present purposes, the summary by Sir Geoffrey Palmer (who was instrumental in the adoption of the scheme) usefully sets down the arguments applied in New Zealand:

The arguments were as follows:

\footnotetext{
${ }^{85}$ Sir Geoffrey Palmer, “"The Nineteen-Seventies”: Summary for Presentation to the Accident Compensation Symposium' (2003) 34 Victoria University of Wellington Law Review 239, 240. ${ }^{86}$ Ibid. A similar observation had been made elsewhere. For example, a well known survey conducted by Terence Ison found that in England 48.9 per cent of money paid into the legal system was spent on its administration: Terence G Inson, The Forensic Lottery (1967), quoted in Peter McKenzie, 'The Compensation Scheme No One Asked For: The Origins of ACC in New Zealand" (2003) 34 Victoria University of Wellington Law Review 193, 197.

${ }^{87}$ Lim Poh Choo v Camden \& Islington Area Health Authority [1980] AC 174, 183 (Lord Scarman).

${ }^{88}$ Michael Tilbury, 'Reconstructing Damages' (2003) 27 Melbourne University Law Review 697, 698. See also McKenzie, above n 86; Stephen Todd, 'Negligence Liability for Personal Injury: A Perspective from New Zealand' (2002) 25 University of New South Wales Law Journal 895, 895.

${ }^{89}$ Ibid; see also: Harold Luntz and David Hambly, Torts: Cases and Commentary ( $5^{\text {th }}$ ed, 2002) 30-63; Hassan El Menyawi, 'Public Tort Liability: An Alternative to Tort Liability and No-Fault Compensation' (2002) 9(4) E-Law: Murdoch University Electronic Journal of Law $<$ http:www.murdoch.edu.au/elaw/issues/v9n4/menyawi94nf.html $>$ at 6 November 2007.
} 
- The failure of the common law to compensate large numbers of accident victims;

- The waste involved in the system in that much of the money was chewed up in legal and administrative expenses;

- The long delays in delivering benefits to those who secured them;

- That personal blameworthiness was not the real rationale for the law because negligence law required individuals to meet the community average standard;

- 'Reprehensible conduct can be followed by feather blows while a moment's inadvertence could call down the heavens' as the Woodhouse Report put it;

- That liability insurance had blunted or removed the deterrent effect of tort law;

- That an assessment of damages in one lump sum involved guesswork and speculation and tended to over-compensate less serious injuries;

- That the process of adjudication was a lottery and impeded the rehabilitation of injured people, and there were strong incentives to maximise misery; and

- Accident prevention was impeded by the system. ${ }^{90}$

The arguments against common law personal injury compensation carried the day. They led to the adoption of the no fault scheme.

Today the scheme is administered by the Accident Compensation Corporation ('ACC') under the Injury Prevention, Rehabilitation and Compensation Act 2001 (NZ). It draws its funding from a number of different sources including employers, income earners, the Government (which makes up the share for non-income earners), and tariffs on petrol and motor vehicle registrations. ${ }^{91}$ It is characterised by periodic claims payments which are paid in weeks and months after the accident rather than years. Also, although it applies to most injuries, it does not purport to cover the field. For example, it does not apply to most mental injuries. ${ }^{92}$ However, the legislation did not abolish those common law causes of action that were not covered and so the

\footnotetext{
${ }^{90}$ Palmer, above n 85, 240-1 (citation omitted).

${ }^{91}$ Accident Compensation Corporation, How ACC is Funded <http://www.acc.co.nz/aboutacc/WCM000119> at 22 November 2007.

92 Although sections 20(4) and 22(6) of the Injury Prevention, Rehabilitation and Compensation Act 2001 (NZ) provide coverage for 'personal injury', section 26 in defining this term only includes mental injuries caused by physical injuries, or those mental injuries falling within the coverage of section 21 (i.e. mental injuries caused by criminal acts).
} 
option of pursuing them still remains. ${ }^{93}$ A plaintiff with such a claim is not left without a remedy. ${ }^{94}$

There are critics of the system, ${ }^{95}$ and clearly it is not perfect. Otherwise its governing legislation would not be regularly amended. ${ }^{96}$ Criticisms range from the expense of the scheme, ${ }^{97}$ to the payments it makes to the injured being too low, ${ }^{98}$ to the notion that the "collectivist vision of community responsibility' represents an attack on the individual. ${ }^{99}$ The removal of faultfinding and its consequent deterrent effect has also been speculated upon $^{100}$ - although, as indicated above, the common law has always been a blunt and imprecise tool for this function, and is relatively feeble compared to its counterpart in the United States. ${ }^{101}$ Deterrence is perhaps a matter best dealt with by suitably empowered professional regulators and, in the most severe cases, by the criminal law. A further criticism is that the scheme has

${ }_{93}$ Injury Prevention, Rehabilitation and Compensation Act 2001 (NZ) s 83.

${ }^{94}$ See, for example, the judgment in Queenstown Lakes District Council v Palmer [1999] 1 NZLR 549.

${ }^{95}$ The most vocal in recent years has been the New Zealand Business Roundtable which has sought a return to private insurance and consumer choice in insurance coverage: Bryce Wilkinson, 'The Accident Compensation Scheme: A Case Study in Public Policy' (2003) 34 Victoria University of Wellington Law Review 313. See also Todd, above n 88, 901.

${ }^{96}$ In addition to minor amendments as may be made to any legislation from time to time, Sir Geoffrey Palmer notes four main versions of the relevant legislation, as follows: Accident

Compensation Act 1972 (NZ); Accident Compensation Act 1982 (NZ); Accident,

Rehabilitation and Compensation Insurance Act 1992 (NZ); and Injury Prevention,

Rehabilitation, and Compensation Act 2001 (Vic); Palmer above n 85, 239-240.

${ }^{97}$ This was a recent concern raised when such a scheme was mooted for Australia. See the discussion in the text below.

${ }^{98}$ This result has been one of the consequences of the amendments of the governing legislation during the last three decades: Duffy above n 84, 368 .

${ }^{99}$ Wilkinson, above $\mathrm{n} 95,325$.

${ }^{100}$ Duffy, above $\mathrm{n} 84,383$.

${ }^{101}$ In the United States, the use of exemplary or 'punitive' damages has seen payments ordered in terms of hundreds of millions of dollars. For example, in Grimshaw v Ford Motor Company 119 Cal App 3d 757 (1981), the Californian Court of Appeal awarded punitive damages of USD125 million against the Ford Motor Company on account of its negligent manufacture and supply of a mass produced motor vehicle which resulted in the death of one plaintiff and serious injury to another. In that case, it was specifically stated that this power to award such damages (which was codified in statute) was specifically intended to provide punishment in cases where government regulation was inadequate. In contrast, in New Zealand such payments are not awarded under the no fault scheme, and in Australia, in those common law jurisdiction where such damages have not been abolished, they are rarely awarded. Regarding the argument that compensatory damages as presently awarded might be viewed as a 'punishment', it has been argued that the realisation of such a concept would be incoherent and would impede the progressive development of the law: Tilbury above n 88,697. The relevant point is that deterrence has rarely been a guiding principle in the awarding of damages in most common law jurisdictions. 
led to an avalanche of claims. However, recent research into medical injuries has established that most people with the basis for a claim do not pursue such compensation. ${ }^{102}$

In summary, today the New Zealand scheme is broadly accepted. It has survived changes of government, and revisions to its legislation, but is still a scheme characterised by its swift compensation of the injured despite its bureaucratic administration. It is a scheme that is frequently described by its supporters as a success. ${ }^{103}$

\section{B The Local Experience of 'No Fault' Schemes}

Australia has had a few experiences of no fault insurance schemes. That which has most in common with the New Zealand scheme was the broadbased scheme proposed in the 1970s when the Labor Government commissioned a report into the matter, that inquiry also chaired by Owen Woodhouse. The scheme that Woodhouse proposed was broadly similar to that in New Zealand, although in certain respects it was more expansive. For example, it extended to all injuries rather than merely those caused by accidents, as was the case in New Zealand. ${ }^{104}$ However, this scheme was never adopted. In many respects this should not be too surprising. First, it threatened some substantial interests in the community who fought it strongly. In an article on the subject, Harold Luntz identifies three significant interest groups that felt threatened by the scheme. ${ }^{105}$ The first group was the legal profession, whose members were threatened with losing part of their livelihood. In this group the Prime Minister of the day, Gough Whitlam, included labour lawyers, usually a group with plaintiffs' best interests in mind, but who in this case were arguably as threatened as defence lawyers. ${ }^{106}$

The second group was made up of the official organisations of the medical profession, which were captured (Luntz suggests) by those of the profession's members who either made a lucrative income from providing medico-legal reports for trials, or who charged higher fees to patients injured

\footnotetext{
102 The study compared review data from the New Zealand Quality of Healthcare Study, which identified 'compensable claims' with a national dataset of actual compensation claims, and found just under 3 per cent of eligible persons actually claimed. See Marie M Bismark et al, 'Claiming Behaviour in a No-Fault System of Medical Injury: A Descriptive Analysis of Claimants and Con-claimants' (2006) 185(4) Medical Journal of Australia 203.

${ }^{103}$ See Todd, above n 88, 896, 901; Luntz, above n 24, 841.

104 Harold Luntz, 'Looking Back at Accident Compensation: An Australian Perspective' (2003) 34 Victoria University of Wellington Law Review 279, 284.

${ }^{105}$ Ibid 286-287.

${ }^{106}$ Gough Whitlam, The Whitlam Government 1972-1975 (1985) 640.
} 
in circumstances where compensation was available. ${ }^{107}$ Apparently, few of these doctors saw that they were sitting on the edge of an age when doctors themselves would become significant targets of negligence claims which would send their own insurance premiums spiralling - something which a no fault scheme would have avoided.

Finally, the third group was the insurance industry. Its members would be deprived not only of significant cash flows but also of access to clients who would take out insurance in more profitable areas. In the 1970s, the insurers were also fighting government proposals to create a government insurer which would compete against them. Thus, as Luntz explains, "[t]heir opposition was fierce, and extended to encouraging their employees to march against an alleged threat to their jobs. ${ }^{108}$

Combined with these opponents were a number of other factors that weakened the cause of the scheme. These included a lack of support from 'natural allies', or support that was qualified or muted. ${ }^{109}$ For example, some trade unions were concerned that their members would be sacrificing rights to 100 per cent of their pre-accident earnings, which existed under some of the state workers' compensation schemes, for the 85 per cent of pre-accident earnings which was being proposed under the no fault scheme. In addition, general coverage and public discussion of the proposal were muted because the Australian Woodhouse Report was but one of a plethora of reports commissioned by the Government at the time; it was effectively one of many gasping for oxygen and which was in short supply. Finally, it must be said that even a government that has broad-based support would probably have a difficult time introducing such a scheme. In 1975, when the legislation was being debated, the scandal-ridden Labor Government at that time was hardly in a good position to implement the scheme.

And yet, despite this environment, when the relevant legislation was considered, a unanimous Senate Committee made up of three government and three opposition members found good cause to consider a new system:

It is clear that the compensation systems are random in their coverage, often provide inadequate compensation and can give rise to inequities. The committee is concerned that existing social service benefits for sickness are inadequate and that compensation for injuries is effectively limited to workcaused injuries suffered by employees, to some victims of criminal acts and

\footnotetext{
${ }^{107}$ Luntz, above n 104, 287.

${ }^{108}$ Ibid 288.

${ }^{109}$ Ibid 285-6.
} 
to those victims of highway accidents who can establish fault in other persons and are not disqualified by want of care on their part. ${ }^{110}$

Warming to its theme, the Committee appears to have then foretold what ultimately occurred in 2002 when it said:

The committee believes that unless significant changes are made to existing remedies for injury, most of which are financed by insurance, their cost will become too high to be financed by insurance premiums and governments will be required to provide supplementary financial assistance. It seems logical to the committee that, if governments are to be required to give financial assistance in this area, it is an appropriate time to consider new approaches to the provision of more equitable and comprehensive coverage at the lowest possible cost... ${ }^{111}$

The only fault which can be found with this prophesy was that the Committee assumed that, somehow, a way would always be found to look after the injured, if not through insurance then through government support. The prospect that plaintiffs would be left totally without means does not appear to have been even contemplated by the Committee as a viable option of social policy. However, seeing problems with the proposed legislation, the Committee required a redraft and the legislation ultimately died with a subsequent change of government and the rallying of those forces opposed to it. $^{112}$

Despite this experience, the introduction of no fault schemes has found favour in various Australian state jurisdictions in the form of limited schemes in areas such as workers' compensation and transport accidents. And yet even the acceptance of these schemes, which only apply in limited situations, has clearly been compromised by political interests and the pressuring of lobby groups. The example of Victoria's Transport Accident Act 1986 is illustrative of this. Introduced during the 1980s by the Labor Government of John Cain, it was conceived as a no fault scheme which would cover the field, abrogating the common law for all claims arising from injuries caused as a result of a transport accident. ${ }^{113}$ However, opposition in the Parliament's

\footnotetext{
${ }^{110}$ Senate Standing Committee on Constitutional and Legal Affairs, Parliament of Australia, Report on the Clauses of the National Compensation Bill (1975) [1.21].

${ }^{111}$ Ibid [1.22].

${ }^{112}$ Apparently the Bill was redrafted and was ready to be introduced in November 1975 just as the Labour Government was dismissed and Parliament dissolved. A subsequent lack of support saw that it was never voted on in the new Parliament: Luntz, above n 104, 289.

${ }^{113}$ Defined to mean 'an incident directly caused by the driving of a motor car or motor vehicle, a railway train or a tram': Transport Accident Act 1986 (Vic) s 3.
} 
upper house meant that the scheme was compromised, ${ }^{114}$ the result being that, under section 93, the option still remained of bringing a common law claim if the accident was classified as 'serious'. ${ }^{115}$ Thus, the scheme introduced was a hybrid. And yet, in an ironic twist, a decade later the Liberal Government of Jeff Kennett adopted the original plan it had earlier opposed when in opposition, and repealed the right to pursue common law claims. Thus, in showing the opportunism which has characterised government actions in relation to this topic, it was then the Labor Opposition which abandoned its old position and, having been encouraged by plaintiff lawyers, promised to restore these limited common law claims. It did this in 2000 after assuming power. ${ }^{116}$ Such is the fate of no fault compensation schemes in Australia.

\section{The 2002 Concerns and Beyond}

The possibility of a no fault scheme was also raised briefly during the crisis in insurance. Early in 2002 as the crisis gained momentum, the Minister for Small Business, Joe Hockey, spoke out, blaming the cost of insurance on the legal profession, and labelling the courts as 'out of control'. His solution was to abolish common law personal injury claims and introduce a New Zealand style no fault scheme. ${ }^{117}$ The swiftness and vehemence of the response to his solution gave a clear indication once again of the forces opposed to such an idea. Within a day of Hockey's comments being reported, responses criticising the no fault scheme were forthcoming from the Law Council of Australia, ${ }^{118}$ the Australian Plaintiff Lawyers Association, ${ }^{119}$ and the Insurance Council of Australia. ${ }^{120}$ However, the strongest criticism was that which came from Senator Helen Coonan who, as the Minister for Revenue and Assistant Treasurer, was Hockey's senior in the Government. Coonan's often repeated (but briefly stated) concern with a New Zealand-type system was the issue of unfunded liabilities that were being experienced with that

\footnotetext{
${ }^{114}$ See Luntz, above n 104, 291.

${ }^{115}$ For a discussion on the meaning of this term, see Mobilio $v$ Bolliotis [1998] VR 833. See also Field, above $\mathrm{n} 61$.

${ }^{116}$ Minister for Workcover, 'Going Forward: Government Delivers On Common Law Rights For Seriously Injured Workers' (Press Release, 11 April 2000) <http://www.dpc.vic.gov.au/ domino/Web Notes/MediaRelArc02.nsf> at 7 December 2007.

117 Toni O'Loughlin and Cynthia Banham, 'Insurance Crisis Leaves Ministers at Odds', Sydney Morning Herald (Sydney), 22 January 2002, 4.

${ }^{118}$ Ibid.

119 Duncan Macfarlane, 'Litigation "Feeding Frenzy"', The Australian (Sydney), 22 January 2002,6 .

${ }^{120}$ Sharon Kemp and Annabel Crabbe with Gabrielle Costa, 'Compensation Scheme Comes Under Fire', The Age (Melbourne), 22 January 2002, 4.
} 
system. ${ }^{121}$ To be specific, for a population of 3 million people, the unfunded liability of New Zealand's Accident Compensation Corporation in 2002 was large, and by 2007 amounted to around NZD14 billion (or AUD 12 billion). ${ }^{122}$

The figure sounds staggering and its apparent magnitude sees it regularly deployed whenever a no fault scheme is suggested. Indeed, it is a favourite device used by critics of the system, and is usually mentioned without either explanation or comparison. Its use without discussion has led Professor Harold Luntz to describe it as 'scare tactics'. ${ }^{123}$ Thus, explaining what is meant by the expression 'unfunded liability' in contrast to 'fully funded liability' in the present context can go some way towards de-sensationalising the facts. The situation was well explained by Andrew Stritch back in the 1990 s, when a return to private insurance was mooted in New Zealand:

Full funding means that the revenue collected in premiums in any one year should cover the total, long-term, costs of the claims occurring in that year. The total costs of a claim can be substantial because people who are permanently disabled in Year 1 will also receive compensation in Years 2, 3 , 4, etc. This may be as much as 40 years worth of payments. To cover all these future payments from revenues collected in Year 1 means that employers, workers and motorists must pay a hefty premium... ${ }^{124}$

In its accounts, New Zealand's ACC includes these future liabilities, even though a significant portion may never be realised. For example, recipients of payments may die earlier than anticipated by the ACC, even though provision might have been made in the ACC accounts for many more years of payments. Other recipients may be sufficiently rehabilitated such that they no longer require payments. However, it is by including them that the deficit is created. And yet,

full funding is unnecessary because there will also be income in future years which can be applied to these future expenses as they arise. As long as your

\footnotetext{
${ }^{121}$ Toni O'Loughlin, 'NZ Way Has its Problems', The Sydney Morning Herald (Sydney), 26 January 2002, 23; Coonan, above n 5; Coonan, above n 20, 823.

$\begin{array}{llllll}122 & \text { Accident Compensation Corporation, Annual Report } 2007 \quad \text { (2007) } & 128\end{array}$ $<$ http://www.acc.co.nz/PRD_EXT_CSMP/groups/external_communications/documents/intern et/dis ctrb097219.pdf> at $1 \overline{1}$ April 2008.

${ }^{123}$ Luntz, above n 24, 841.

${ }^{124}$ Andrew Stritch, 'Competition and Compensation: The Privatisation of the ACC' (1998) 11 Social Policy Journal of New Zealand 1, $3<$ http://www.msd.govt.nz/publications/journal/11december-1998/index.html\#4> at 7 December 2007.
} 
current year's income covers your current year's expenses, your accounts will be happily in balance, and you may even have a surplus for savings. ${ }^{125}$

Stritch then goes on to explain that families, corporations, public institutions and government agencies all operate quite successfully on this pay as you go basis. In this way, the 'unfunded liability' should not appear so ominous. . $^{26}$ Indeed, viewed this way, the no fault scheme in New Zealand appears very similar to a social security scheme (on which it might be observed uncompensated injured persons would otherwise have to rely).

Add to this understanding the fact that in cases in Australia where the common law either provides no compensation or the lump sum awarded is found years later to be inadequate, and the fallacy of the comparison between the common law in Australia and the 'unfunded no fault scheme' in New Zealand is exposed. It is not the case that the former provides cover for all. The fact is that the common law is no longer so expansive. Also, it is not the case that the latter is a precarious bureaucratic structure always on the verge of collapse. The fact is that the ACC is a far healthier beast than its detractors would have the world believe.

Having made these points, it is worth reflecting that the arguments proposed in New Zealand in support of the no fault scheme over the common law have not diminished and are just as applicable in Australia. Indeed, in the years since the crisis in insurance, those arguments have been magnified. In contrast to New Zealand's no fault scheme that did not abolish claims that did not fall within its terms, much of the then new Australian legislation had precisely this characteristic. In addition, despite the abrogation of such claims, the delays in litigation have remained. Indeed, as recently as December 2007, Victoria's Chief Justice Marilyn Warren was reported as

\footnotetext{
${ }^{125}$ Ibid 3-4.

${ }^{126}$ Even so, in defence of the ACC some statement should be made against the allegation that it will always be funded in this way. Specifically, in its 2007 Annual Report, the ACC addressed this issue by way of explaining why it had generated an operating surplus for the year: the surplus was intended to generate investment capital so as to eventually achieve 'fully funded' status. In addition, the ACC was able to say that its reserves portfolios had grown 16 per cent in the preceding year, to NZD 9.2 billion at 30 June 2007: Accident Compensation Corporation, , above $\mathrm{n} \mathrm{122,47.} \mathrm{This} \mathrm{is} \mathrm{an} \mathrm{existing} \mathrm{sum} \mathrm{greater} \mathrm{than} \mathrm{half} \mathrm{of} \mathrm{the} \mathrm{unrealised}$ 'unfunded' liability of NZD 14 billion noted above.

However, even if full funding were required for such a scheme should it be adopted in Australia, when it is recalled that in late 2007 Australians witnessed an election campaign in which both sides of politics offered over $\$ 30$ billion in tax cuts, there is a clear suggestion that the coffers of the Commonwealth Government are over full. See Brendan Nicholson, 'Tax Cuts of \$34 billion', The Age (Melbourne), 15 October 2007.
} 
seeking more judges and more space for trials, the volume of cases before the Supreme Court having bottlenecked the system. ${ }^{127}$ On the same day, another senior judge, Justice David Byrne, was reported as wanting barristers to 'pare down their point scoring and abandon all but the most contentious issues before a case gets to trial' ${ }^{128}$ These views appear to echo similar comments made by former High Court Justice Ian Callinan a month earlier when he pointed to problems with the adversarial system being too long and costing too much. ${ }^{129}$ Thus, perhaps it is from the High Court that a final example should be drawn of how the common law can be a black hole of inefficiency. Specifically, when it is recalled that in 2005 the High Court heard four cases all involving diving accidents in which plaintiffs suffered spinal injuries, cases in which judges at all levels differed in their opinions, ${ }^{130}$ a level of waste and uncertainty in the fault-finding exercise is difficult to not to perceive. This impression is derived even when not taking into account the diving cases that did not reach the High Court. It poses the question: how much of this expense could have been better spent compensating the injured?

\section{CONCLUSION}

Should Australia introduce a no fault injuries compensation scheme?

It sounds like an anathema to make such a suggestion; a return to welfare state thinking, the 1940s, and schemes that crippled national economies through the 1950s and 1960s. And yet the reasoning behind adopting such a scheme is not about social restructuring, or creating a soft-hearted 'caring society'. It is ultimately about dollars and cents - the most efficient use of those dollars and cents - and also about fairness.

Of course, this question feeds directly into the broader philosophical debate which places the fault concept underlying tort law, and its associated notions of individual responsibility, against the concept of loss spreading whereby the community shares in compensating for the injuries suffered by its members, regardless of a finding of fault. That argument has been restated

\footnotetext{
${ }^{127}$ Leonie Wood, 'Chief Seeks New Judges and Courts', The Age (Melbourne), 8 December 2007, 11

${ }^{128}$ Leonie Wood, 'Judge Looks to Simplify Cases and Cut Costs', BusinessDay, The Age (Melbourne), 8 December 2007, 3.

129 AAP, 'Judge Rues "Personal Baggage" of Colleagues', The Age (Melbourne), 24 November 2007, 9.

${ }^{130}$ Swain v Waverley Municipal Council (2005) 220 CLR 517; Waterways Authority v Fitzgibbon (2005) 221 ALR 402; Vairy v Wyong Shire Council (2005) 223 CLR 422; Mulligan $v$ Coffs Harbour City Council (2005) 223 CLR 486.
} 
many times, ${ }^{131}$ but any clarity that might have once existed in its practical application is at best hypothetical in twenty-first century Australia. Tort law as applied by the courts involves identifying the individual responsibility of a tortfeasor for his or her wrongs and requiring that tortfeasor to make good the damage caused by those wrongs. However, inherent in the 'crisis in insurance' was the fact that most tortfeasors were not ultimately subjected to the full weight of such findings, or the associated deterrent effect, because their actions were underwritten by their insurers. In other words, loss spreading was already occurring, albeit to an extent limited by the number of other policy-holders insured by the common insurer. If it remains the accepted assumption that the community should provide some method of compensating injured people in certain cases, ${ }^{132}$ then the move towards a no fault scheme would simply be extending this trend, while at the same time removing the costly incidents of litigation and private indemnification.

The no fault scheme which Australia first considered was not a post-war reward for victory over the invader, which is an often repeated reason for Britain's post-war welfare revolution. Rather, what Australia considered adopting in the 1970s was a new approach to the dilemma of inefficient and expensive methods of providing for the injured. That a Senate Committee composed equally of Government and Opposition senators advocated such a scheme (albeit with some tinkering), speaks volumes about the attractiveness of the scheme. As the bi-partisan approach indicates, this was not an issue of political philosophy. It was a pragmatic issue of dollars and cents.

That such a scheme was not adopted can be attributed to a number of factors. Well and loudly spoken vested interests against were one factor frequently cited. When combined with higher time-consuming political priorities, they helped spell the death knell of the scheme. However, possibly the most significant argument was that the common law at that time still functioned in a largely unfettered way. There were no injury thresholds to be cleared before

\footnotetext{
${ }^{131}$ See, for example: Luntz and Hambly, above $\mathrm{n} 89$, ch 1; John G Fleming, The Law of Torts ( $9^{\text {th }}$ ed, 1998) 8-17; Peter Cane, The Anatomy of Tort Law (1997) ch 7.

${ }^{132}$ Importantly, it should be recognised that not all conceptions of the law of torts adopt this function as its pre-eminent purpose. For example, law and economics scholars argue that the economic justification of the law of torts is that it encourages deterrence, by holding such individuals responsible for their inefficient tortious acts that detract from the social wealth. As has been surmised: 'The purpose of awarding damaged to $\mathrm{P}$ is not to protect $\mathrm{P}$ 's interest but to give an incentive to D not to engage in the future in inefficient conduct': Cane, above n 131, 221-222. Thus, for contrast, a useful survey of the ways leading United States law and economics scholars (including Guido Calabresi and Richard Posner) approached the personal injuries and compensation debate in the 1970s, see Richard Gaskins, 'The Fate of No-Fault in America' (2003) 34 Victoria University of Wellington Law Review 213.
} 
you could sue and no limits on damages if the damage established was great. The arguments in favour of the common law quite easily held sway, and it is understandable why this was so. Although not perfect, it is often said that the hallmark of the common law is fairness.

However, times and the law have changed. The analogy with a card game is apt. In the 1970s, and for a long time after, the plaintiff claiming for personal injury still had some winning hands to play. It was a fairer contest. However, after the 2002 crisis in insurance and the legislative changes introduced, plaintiffs saw the aces removed from their hands. The defendants and their insurers were given a loaded deck and the ability to fight a claim knowing that the most extreme damages claims were capped (along with the dangers of contesting them). These people were also strengthened in the knowledge that most pain and suffering claims were now denied. In practical terms, the denial of such multiplicitous claims helped increase their bottom line.

In plain terms, the rights of plaintiffs were taken away to assist financially challenged private businesses. What was already a hybrid common law system - on account of the limited no fault compensation schemes for some injuries - was emasculated. The strengths of the common law were removed. Almost immediately after the changes were first introduced, and for each of the five years thereafter, the insurance firms which lobbied so hard for the changes have been returning profits which are counted in the billions of dollars. In contrast, many plaintiffs are the poorer, and their pain and suffering is often set at nought. Their defender - the common law - is but a pale imitation of its former self. Meanwhile, the negligent defendants who caused that pain and suffering are largely untouched. Where is the deterrence in that?

So this is the question: when viewing the present complex and restrictive state of the common law, should we now be considering alternatives? Whether the best alternative is merely a winding back of the legislation of 2002 and 2003, or a wholesale return to the common law, or as a further alternative the adoption of a no fault compensation scheme, is a moot question. Although flaws with the common law have been noted, a windback is possible. The common law has its defenders. This is understandable. Many defence lawyers extol its virtues as a separator of the meritorious claims from the frivolous cases. ${ }^{133}$ Further, to give it due credit, it has served many a plaintiff well.

${ }^{133}$ At the same time, this argument can involve overstatements of the common law system's strengths, and a convenient gloss over its shortcomings. For example, during the preparation of 
In contrast, if the no fault option was pursued, although it could cut through many of the problems of the adversarial system, it could also produce an ironic twist. Specifically, there is more than a possibility that the same insurers who decried the excesses of the common law could become its greatest defenders, the threat of being banished from the system and extra premiums arguably being too much for the industry to bear. Such a threat could possibly also turn them into advocates of a wind-back of some of the amendments of 2002 and 2003.

And yet, whichever option is ultimately adopted, there is at least one certainty. It is apparent when the present system is observed. It is certain that that there must be a better way.

this article, it was suggested to the author viva voce that many conscientious defence lawyers can claim they have 'never lost a case' because they settle those which present meritorious claims, and only contest at trial those claims where the defendant's negligence cannot be proved. And yet while such a claim is clearly good evidence of the finely tuned skills of these trial lawyers, what it fails to address is that plaintiffs with meritorious claims might have good reasons for settling claims for lesser sums of compensation than may be warranted by an injury, and that the reasons for settling for lesser sums may be more pragmatic. They might be based in many matters, including: concerns about the time it takes to get to trial; the stress involved in going to trial (which may be exacerbated in the case of injured persons); the concerns with how well witnesses may present as the interval between accident and trial grows (meaning that the 'testing' of the evidence is not actually a testing of the 'best' and freshest evidence); and the realisation that sometimes the unexpected can occur during trials. In addition, while some of these matters might be resolved on appeal, this time interval can exacerbate the 'justice delayed'. In summary, rather than being a complete argument in favour of the strengths of the common law for both defendant and plaintiff, this argument neglects the fact that the best settlement for a negligent defendant is not necessarily the best settlement for an innocent plaintiff who may have legitimate concerns about going to trial which are unconnected with the merits of his or her case. 